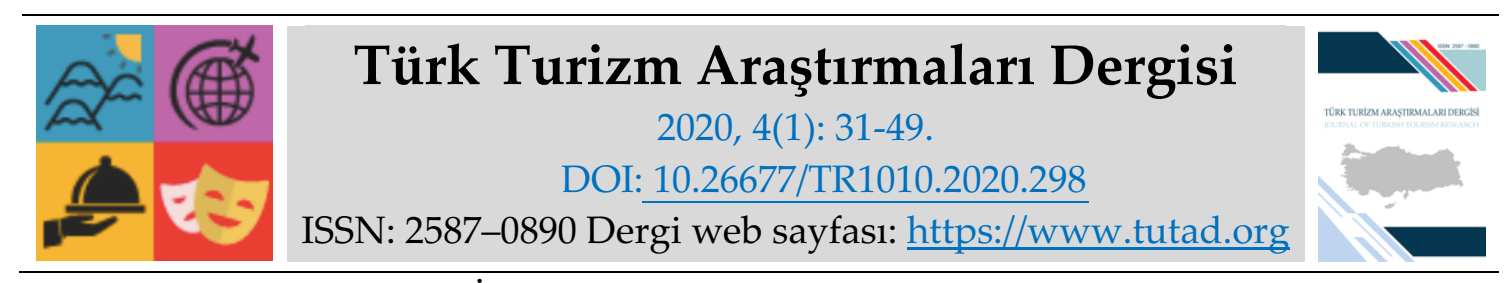

ARAȘTIRMA MAKALESI

\title{
Turizm Rehberliği Öğrencilerinin Gözünden Kuşadası'nın Destinasyon İmajı ve Destinasyon Kişiliği: Aydın Adnan Menderes Üniversitesi Turizm Fakültesi Örneği
}

Arş. Gör. Turan OKUL, Adnan Menderes Üniversitesi, Turizm Fakültesi, Aydın, e-posta: turanokul@hotmail.com

ORCID: https://orcid.org/0000-0003-2129-3271

Dr. Öğr. Üyesi Tuğrul AYYILDIZ, Adnan Menderes Üniversitesi, Turizm Fakültesi, Aydın, eposta: tayyildiz@adu.edu.tr

ORCID: https://orcid.org/0000-0001-6332-975X

Dr. Öğr. Üyesi Ahu YAZICI AYYILDIZ, Adnan Menderes Üniversitesi, Turizm Fakültesi, Aydın, e-posta: ayazici@adu.edu.tr

ORCID: https://orcid.org/0000-0002-1301-2428

Öz

Destinasyonlar arası rekabetin oldukça arttı̆̆ günümüzde pazarlama açısından destinasyonların sahip oldukları imaj ve kişilikleri bu destinasyonların tercih edilebilirliklerinde önemli birer rol oynamaktadır. Turistlerin destinasyon imajı ve destinasyon kişiliği algılamalarında önemli bir role sahip olan turist rehberlerinin gözünden tanıtımlarını yaptıkları birçok turisti gezdirdikleri destinasyonun, imajını ve kişiliğini nasıl algıladıkları da bir o kadar önemlidir. Buradan hareketle, çalışmanın temel amacı geleceğin turist rehberi adayı olan Aydın Adnan Menderes Üniversitesi Turizm Fakültesi Turizm Rehberliği bölümü öğrencilerinin Kuşadası destinasyon imajı ve destinasyon kişiliği algılamaları arasındaki ilişkiyi ortaya koymaktır. Çalışmada Aydın Adnan Menderes Üniversitesi Turizm Rehberliği bölümünde eğitimine devam eden tüm öğrencilerden veri toplanmaya çalışılmıştır. Çalışmada veri toplama tekniği olarak anket kullanılmıştır. Öğrencilerin demografik özelliklerine göre yapılan karşılaştırılmalı analizlerde öğrenim görülen sınıfa göre anlamlı farklılıklar olduğu ortaya koyulmuştur. Destinasyon imajı boyutları ile destinasyon kişiliği boyutları arasındaki korelasyon analizi sonucunda tüm destinasyon imajı boyutları ile tüm destinasyon kişiliği boyutları arasında istatistiksel olarak anlamlı ilişki olduğu tespit edilmiştir.

Anahtar Kelimeler: Destinasyon İmajı, Destinasyon Kişiliği, Turist Rehberi, Kuşadası.

Makale Gönderme Tarihi: 15.10.2019

Makale Kabul Tarihi: 09.01.2020

Önerilen Atıf:

Okul, T., Ayyıldız, T. ve Yazıcı Ayyıldız, A. (2020). Turizm Rehberliği Öğrencilerinin Gözünden Kuşadası'nın Destinasyon İmajı ve Destinasyon Kişiliği: Aydın Adnan Menderes Üniversitesi Turizm Fakültesi Örneği, Türk Turizm Araştırmaları Dergisi, 4(1): 31-49.

(C) 2020 Türk Turizm Araştırmaları Dergisi. 


\title{
Journal of Turkish Tourism Research
2020, 4(1): $31-49$. \\ RESEARCH PAPER
}

\section{The Destination Image and Destination Personality of Kuşadası from the View of Tourism Guiding Students: The Case of Aydın Adnan Menderes University Faculty of Tourism}

Research Assistant Turan OKUL, Adnan Menderes University, Faculty of Tourism, Aydın, email: turanokul@hotmail.com

ORCID: https://orcid.org/0000-0003-2129-3271

Assistant Prof. Dr. Tuğrul AYYILDIZ, Adnan Menderes University, Faculty of Tourism, Aydın, e-mail: tayyildiz@adu.edu.tr

ORCID: https://orcid.org/0000-0001-6332-975X

Assistant Prof. Dr. Ahu YAZICI AYYILDIZ, Adnan Menderes University, Faculty of Tourism, Aydın, e-mail: ayazici@adu.edu.tr

ORCID: https://orcid.org/0000-0002-1301-2428

\begin{abstract}
Competition between destinations is increasing. In terms of marketing, the image and personalities of the destinations play an important role in the preferability of these destinations. Tourist guides play an important role in tourists' perception of destination image and destination personality. Therefore, how tourist guides perceive the image and personality of the destination is thought to be as important. From this point of view, the main purpose of the study is to reveal the relationship between destination image and destination personality of Aydın Adnan Menderes University Tourism Faculty Tourism Guidance Department students. In this study, data was collected from all students who are continuing their education in Aydin Adnan Menderes University Tourism Guidance Department. In this study, a questionnaire was used as data collection technique. According to the demographic characteristics of the students, it was revealed that there were significant differences according to the class of study. As a result of the correlation analysis between destination image dimensions and destination personality dimensions, a statistically significant relationship was found between all destination image dimensions and all destination personality dimensions.
\end{abstract}

Keywords: Destination İmage, Destinasyon Personality, Tourist Guide, Kuşadası.

Received: 15.10 .2019

Accepted: 09.01.2020

Suggested Citation:

Okul, T., Ayyıldız, T. and Yazıcı Ayyıldız, A. (2020). The Destination Image and Destination Personality of Kuşadası from the View of Tourism Guiding Students: The Case of Aydın Adnan Menderes University Faculty of Tourism, Journal of Turkish Tourism Research, 4(1): 31-49.

(C) 2020 Türk Turizm Araştırmaları Dergisi. 


\section{GİRIŞ}

Günümüz rekabet koşulları içerisinde markalar giderek birbirlerine daha çok benzemektedir. Bu bağlamda bir markayı diğerinden ayıran, onu farklı kılan özellikleri bulmak daha da zor bir hal almaktadır. Pazarda sağladıkları işlevsel fayda açısından aynı sayılabilecek birçok ürün ya da hizmet yer almaktadır. Bu noktada marka devreye girerek, tüketiciyi satın almaya yönlendiren en önemli öğelerden biri olmuştur. Tüketiciler ürün ya da hizmetleri satın alırken onların işlevsel faydalarından ziyade marka imajının ve kişiliğinin kendileri için ne ifade ettiğine göz önüne almaktadırlar (Özüpek ve Diker, 2013). Turizm endüstrisi de günden güne gelişimini devam ettirmekte olan dinamik bir endüstridir. Günümüzde bir yandan turizm işletmeleri arası rekabet yaşanırken bir yandan da turizm bağlamında ülkeler arası rekabet yaşanmaktadır. Elbette her ülke büyük bir pasta olan turizm gelirlerinden daha büyük bir dilim alma çabası içerisindedir. Ülkeler bu rekabeti sahip oldukları destinasyonlar üzerinden gerçekleştirmektedirler. Pazarlama faaliyetleri de destinasyonların sahip oldukları farklı çekiciliklerin ön plana çıkarılması ile gerçekleştirilmektedir. Bu anlamda destinasyonlar markalanmaya başlamıştır (Kotler ve Gertner, 2002; Morgan vd., 2011). Ekinci ve Hosany (2006) da çalışmalarında destinasyonların bir ürün veya marka olarak düşünülebileceğini ortaya koymuştur. Buradan yola çıkarak, destinasyonların pazarlamasında ve markalanmasında, destinasyon imajı ve destinasyon kişiliği kavramlarının ön plana çıtığı görülmektedir. Böylece, imajı ve kişiliği güçlü olan destinasyonlar pazarlama açısından da diğer destinasyonlar karşısında bir adım öne çıkmaktadır. Bu destinasyonlar turistlerin satın alma kararlarında en önemli faktörler arasında yer almaktadır.

Turizm endüstrisinde destinasyonlar temel çekiciliklerden bir tanesi konumundadır. Gelen ziyaretçilere destinasyonları gezdiren ve orası hakkında bilgiler veren turist rehberlerinin, ziyaretçilerle doğrudan etkileşim içerisinde olması ve onları yönlendirmesi sebebi ile destinasyonun tanıtımı ve destinasyonun imajı konusunda ziyaretçiler üzerinde etki sağlayabileceği düşünülmektedir. Böylece, ziyaretçilerin bir destinasyonun imajı ve kişiliği hakkındaki algıları kadar turist rehberlerinin de o destinasyonun imajı ve kişiliği hakkındaki algılarının önemli olduğu fikri akla gelmektedir.

Dünya Rehberler Federasyon Örgütü (WFTGA) turist rehberini; turistlere tercih ettikleri lisanda rehberlik eden, bulundukları bölgenin doğal ve kültürel miraslarını onlara tercüme eden ve bulunduğu bölgedeki yetkili bir idare tarafından kabul görmüş donanımına sahip kişi şeklinde tanımlamaktadır (What is a Tourist Guide?, 2019; wfgta.org). Bir başka tanıma göre ise turist rehberi; turistlere ve ziyaretçilere eşlik ederek; sit alanları, müzeler, anıtlar, türbeler, mabetler, tarihi eserler ve kalıntılar, folklor, kültür, sanat eserleri, el sanatları, hatıra eşyaları, eğlence yer ve olanakları hakkında doğru bilgiler verip gezdiren, gerektiğinde yaylacılık, dağ ve doğa yürüyüşleri, su sporları, avcllık, kayak, mağaracılık, paraşütçülük, botanik, bisiklet ve at turlarını kapsayan çeşitli spor türlerinin uygulanmasına yardımcı olan kişi olarak ifade edilmektedir (Ahipaşaoğlu, 2001). Turist rehberliği eğitimi veren kurumların sayısı ülkemizde giderek artış göstermektedir. Bu eğitim kurumlarında yetişen öğrenciler geleceğin turist rehberi adayı konumundadır. Bu sebeple, turist rehberlerinin ziyaretçileri gezdirdikleri ve tanıttıkları destinasyon hakkındaki imaj ve kişilik algılarının önemli olabileceği kadar turist rehberi adayı olan rehberlik öğrencilerinin algıladıkları imaj ve kişiliğin de önemli olacağı söylenebilir. Buradan hareketle, araştırmanın sorun cümlesi şu şekilde ifade edilmiştir: Turizm rehberliği bölümü öğrencilerinin bulundukları destinasyon ile ilgili algıladıkları destinasyon imajı ve destinasyon kişiliği arasında anlamlı bir ilişki bulunmakta mıdır? 
$\mathrm{Bu}$ araştırmanın temel amacı, Aydın Adnan Menderes Üniversitesi Turizm Fakültesinde öğrenim gören turizm rehberliği bölümü öğrencilerinin Kuşadası ile ilgili algıladıkları destinasyon imajı ve destinasyon kişiliği arasındaki ilişkiyi ortaya koymaktır.

\section{DESTINASYON İMAJI VE DESTINASYON KIŞİLIĞ́̇}

Oldukça rekabetçi bir küresel ortamda, geniş turizm destinasyon seçenekleriyle, güçlü bir marka ve cazip bir imaj karar verme sürecinde ve kişisel deneyime dayanan destinasyon ile ilgili tatmin düzeyi oluşturmada önemli bir rol oynar. "Gerçeklikten daha önemli" olarak kabul gören destinasyon imajı potansiyel turistlerin karar verme davranışı için belirleyici bir faktördür. Destinasyon imajı söz konusu destinasyonu diğer destinasyonlardan farklılaştırmakta ve müşterilerin zihinlerinde konumlandırmaktadır (Ahmodova, 2018). Destinasyon imajı akademik literatürde 30 yıldan fazla bir süredir ele alınıp incelenen önemli bir konudur. Bu kavramın önemi ilk olarak Hunt (1975) tarafından ortaya konmuştur. Gallarza, Gil Saura ve Garcia (2002) destinayon imajı ile ilgili literatüre ilk kapsamlı katkıyı sağlamışlar ve destinasyon imajını karmaşık, çok boyutlu ve dinamik bir kavram olarak tanımlamışlardır. Birçok araştırmacı destinasyon imajını ölçmeye çalışmış ancak ölçümlerin geçerliliği ve güvenilirliği nedeniyle başarısız olurken bu konuda çok az sayıda araştırmacı başarılı olmuştur (Artuğer ve Çetinsöz, 2017).

Destinasyon imajı ile ilgili birçok tanım bir yerin bireysel veya grup algılarını ifade eder. Destinasyon imajının sadece yapının çoklu boyutlarını (bilişsel, duyuşsal ve konvansiyonel), göstermeyen aynı zamanda bir destinasyon hakkındaki karar üzerine etkilerini de belirten bir destinasyona yönelik düşünceler fikirler duygular, görselleştirmeler ve niyetlerin etkileşimli bir sistemi olduğu belirtilmektedir. (Tasci ve Gartner, 2007; Allameh vd., 2014). Bir çalışmada "destinasyon imajı" terimi sıklıkla kullanılmamaktadır. Ancak, bunlar bu terim tam olarak kavramsallaştırmama eğilimindedirler. Beerli ve Martin, (2004) bu kavramın ampirik bağlamda kullanılmasına rağmen iyi bir şekilde tanımlanmadığına ve sağlam bir kavramsal yapıdan yoksun olduğuna dikkat çekmektedirler. Çok sayıda bilim insanı destinasyon imajı ile ilgili biraz farklı tanımlarını ortaya koymuşlardır (Hunt, 1975; Kim ve Richardson, 2003; Lawson ve Baud-Bovy, 1977). Kim ve Richardson, (2003) destinasyon imajin potansiyel turistlerin bir bölge hakkındaki algıları olarak tanımlamışlardır. Lawson ve Baud-Bovy (1977) destinasyon imajını bir birey veya grubun belirli bir nesneye veya yere ait tüm bilgilerin, izlenimlerin, önyargıların ve duygusal düşüncelerin ifadesi olarak tanımlamışlardır (Baloğlu ve McCleary, 1999). Crompton (1979), destinasyon imajını, bir bireyin belirli bir destinasyona karşı sahip olduğu bilişsel inançların ve duygusal izlenimlerin toplamı olarak kavramsallaştırmıştır. Benzer bir biçimde Baloğlu ve Bringerg (1997) ve Beerli ve arkadaşları (2002), destinasyon imajını hem yüksek düzeyde bilişsel yönlerden (inanç) hem de duygusal yönlerden (duygu) oluşan öznel algılarla tanımlanmaktadır. Destinasyon imajının ölçümü hem bilişsel hem de duygusal yönleri yansitmalıdır (Byon ve Zhang, 2010).

Markaların sembolik olarak kullanımın mümkün olduğu, çünkü tüketicilerin markaları insan kişilik özellikleri ile sık sık kullandığı iddia edilmektedir. Marka kişiliğgi "marka ile ilişkilendirilen insan özellikleri kümesi" olarak tanımlanmaktadır (Aaker, 1997). İnsanlar arkadaşlarını seçtikleri gibi, kendileri gibi yetenek ve fiziksel özelliklere sahip olduklarını düşündükleri markaları da seçerler. Marka kişiliği tüketiciler için performans odaklı olmayı ifade eder. Marka kişiliği tüketicilerin kendini temsil etmesinin veya ifade etmesinin en etkili yollarından birisi olarak kabul görmektedir (Özer, 2015). Destinasyon kişiliği ile ilgili olarak çalışmalar yapan araştırmacılar (Ekinci ve Hosany, 2006; Beerli ve Martin, 2004), pazarlama literatüründe 1960 'lı yıllardan bu yana yer alan marka kişiliği kavramını, turizm literatürüne 
uyarlayarak çalışmalarını gerçekleştirmektedirler. Dolayısıyla destinasyon kişiliğii, bir markaya ait kişilik özelliklerinin destinasyonlarda da var olabileceği düşüncesi ile ortaya çıkıştır (Çelik vd., 2019). Destinasyon kişiliği, bir yerin sahip olduğu işlevsel, deneyimsel ve sembolik özellikleri olarak tanımlanmıştır (Hankinson, 2004 akt. Türkmen, Atay ve Türkmen, 2018). Herhangi bir insandan söz ederken erkeksi, kadınsı, eğlenceli, genç, yaşlı, güçlü, cesur, enerjik gibi kişilik özellikleri söylenebilir. Pazarlama araştırmacıları tarafından "Destinasyonlar bir kişiliğe sahip olabilir mi?" sorusu insanbiçimcilik teorisine dayandırılmaktadır. Bu teoriye ışığında, ürünler veya markalar insani varlık taşımasa da tüketiciler insani varlık taşımayan ürünleri veya markaları sanki bir insani varlıkmış gibi algılayarak, onlara insani özellikler yüklemektedirler. Bu kişilik özellikleri de markaya atfedildiği zaman tüketicilerin markayı tercih etmesine katkı sağlamaktadır (Güzel vd., 2018).

Turizm destinasyonlarının sayılarının giderek artması, ulaşım olanaklarının kolaylaşması, insanların boş zamanlarının daha da artması gibi nedenlerden dolayı turistlerin destinasyon seçimi gerçekleştirirken zorlanmalarına ya da daha seçici davranmalarına sebep olmaktadır. Markalaşma sonucu ortaya çıkan destinasyon kişiliği ile turistlerin destinasyona olan ilgileri artmakta ve turistlerin destinasyon seçimleri etkilenebilmektedir. Destinasyon kişiliği sayesine turistler farklı destinasyonları birbirlerinden kolayca ayırt edebilmektedirler ve yine destinasyon kişiliği sayesinde turistler destinasyon hakkında olumlu bir imaj geliştirebilmektedirler (Guthrie, Kim ve Jung, 2008). Böylece turistler destinasyon ile aralarında güçlü bir bağ kurarak destinasyonu tercih etmekte ve tekrar ziyaret etmek istemektedirler (Ülkü, Solmaz ve Barakazı, 2017).

Ekinci ve Hosany (2006), yapmış oldukları çalışma ile Aaker'in (1997) marka kişiliğini turizm destinasyonlarına ilk defa uyarlayarak ölçen kişiler olmuşlardır. İki farklı örneklem grubunda araştırma gerçekleştirmişlerdir. Destinasyon kişiliğini üç boyutta ortaya koyan araştırmacılar hem uluslararası seyahat eden turistler hem de sadece İngiliz turistler üzerinde araştırmayı gerçekleştirmişlerdir, bu boyutlar; samimiyet (güvenilir, samimi, zeki, başarılı, erdemli), heyecan (heyecanlı, cesur, özgün, canlı) ve eğlence (arkadaşça, aile odaklı, büyüleyici) şeklinde ortaya koyulmuştur.

Bir turizm ürünü olarak bir destinasyon aynı zamanda bir kişiliğe sahiptir ve diğer tipik ürünler gibi destinasyon imajı özellikleri de destinasyon kişilik özellikleri üretebilir. Destinasyon imajının bir bileşeni destinasyonun kişiliği veya karakteridir (Bilim ve Bilim, 2014). Marka imajı ve marka kişiliği, marka sadakati ve marka konumlandırmanın temel bileşenleridir. İki kavramı açıklamak için çeşitli modeller mevcut olsa da marka imajı ile marka kişiliği arasındaki ilişkiyi açıklamada birçok belirsizlik bulunmaktadır. Zayıf kavramsallaştırma ve ampirik çalışmaların eksikliği bu iki kavram arasındaki ilişkiyi anlamayı zorlaştırmaktadır. Teorik düzeyde, tanımsal tutarsızlıklar ve marka kişiliği ile marka imajı terimlerinin birbirinin yerine kullanımı şeklinde iki konu tanımlanabilmektedir. Patterson'un (1999) marka literatürünü gözden geçirmesi ile yaptığı çalışmada, 27 marka imajının tanımını ve 12 marka kişilik tanımını ortaya koymuştur. Bazı durumlarda marka imajı, marka kişiliği açısından tanımlanmıştır (Hosany vd., 2006).

Artuğer ve Çetinsöz (2014) destinasyon imajı ile destinasyon kişiliği arasındaki ilişkiyi belirlemeye yönelik bir araştırma başlıklı çalışmalarında; Destinasyon imajı ile destinasyon kişiliği arasındaki ilişkiyi belirlemeyi amaçlamışlar ve duygusal imaj ile destinasyon kişiliği arasında negatif yönlü ve çok zayıf bir ilişki olduğu, buna karşın bilişsel imaj ile destinasyon kişiliği arasında ise pozitif yönlü ve kuvvetli bir ilişki olduğunu tespit etmişlerdir. Ekinci ve Hosany (2006) yaptıkları çalışmada özellikle eğlenceli boyutun bilişsel imaj üzerinde etkisi olduğunu ortaya koymuşlardır. Hosany vd., (2006)'nın yaptıkları çalışmada da destinasyon imajının duygusal bileşeninin destinasyon kişiliği boyutlarında etkili olduğunu ortaya 
koymuşlardır. Kim vd., (2017)'nin yaptığı çalışmada da destinasyon kişiliği üç boyutunun destinasyon imajını etkilediği görülmektedir. Chen ve Phou (2013) yaptıkları araştırmada destinasyon imajı ile destinasyon kişiliği arasında pozitif bir ilişki olduğunu bulmuşlardır. Papadimitriou, Apostolopoulou ve Kaplanidou (2015) yaptıkları çalışmada da benzer şekilde destinasyon kişiliğinin destinasyon imajını pozitif yönde etkilediği görülmektedir. İlgili literatür incelendiğinde çalışmaların genellikle ziyaretçiler üzerinde gerçekleştiği ve turizm rehberleri, turizm rehberliği öğrencileri üzerinde yapılan çalışmaların ise yok denecek kadar az olduğu görülmektedir.

\section{YÖNTEM}

\section{Araştırmanın Amacı}

Destinasyon imajı ve destinasyon kişiliği günümüzde insanların seyahatlerinde destinasyon tercihlerini etkileyen önemli faktörler arasında yer almaktadır. Destinasyon imajı ve destinasyon kişiliği kavramları içerisinde birçok soyut ve somut özellikler bulunmaktadır. Destinasyon imajı ve destinasyon kişiliği kavramları insanların tatil satın almalarında satın alma öncesi evrede, tatil evresinde ve satın alma sonrası evrede turistleri önemli derece de etkilemektedir. Turistler tatil satın alma evresinde kendilerine göre destinasyon imajı ve destinasyon kişiliği olumlu buldukları yerleri tercih edeceklerdir. Tatil evresinde kendilerince destinasyon imajı ve kişiliği olumlu olan destinasyonda daha mutlu bir tatil geçireceklerdir. Son olarak tatil sonrası evrede ise yine kendilerince destinasyon imajı ve kişiliği olumlu olan destinasyonda tatil yapmanın mutluluğunu yaşayacaklar bu durumda onların o destinasyonu tekrar ziyaret etme olasılıklarını arttıracaktır. Turist rehberleri tatil esnasında turistlerin algıladıkları destinasyon imajını ve destinasyon kişiliğini olumlu ya da olumsuz etkileyebilirler. Destinasyonla ilgili olarak öncelikle tanıtımını yapacakları turiste bilgi verecekleri yer ile ilgili olarak turist rehberlerinin destinasyon imajı ve destinasyon kişiliği algıları önem arz etmektedir. Umur ve Eren (2015)'e göre, ziyaretçilerin destinasyon hakkındaki bilgileri öğrenme sürecini hızlandıracak yöntemler kullanılarak, ilgili destinasyonu tercih etmesine çaba gösterilmelidir. Olumsuz destinasyon imajı ve kişiliği algısı olan bir kişinin o destinasyon ile ilgili tanıtım yaparken sıkıntılar yaşayabileceği düşünülmektedir. Bu noktada turist rehberi adaylarının da destinasyon imajı ve kişiliği algılarının önemli olduğu düşünülmektedir. Bu doğrultuda bu çalışmanın temel amacı Aydın Adnan Menderes Üniversitesi Turizm Fakültesinde öğrenim gören turizm rehberliği bölümü öğrencilerinin Kuşadası ile ilgili algıladıkları destinasyon imajı ve destinasyon kişiliği arasındaki ilişkiyi ortaya koymaktır.

\section{Araştırma Yöntemi}

Bu çalışma nicel araştırmalardan ilişkisel bir çalışmadır. Çalışma 2019 yılı ocak ayı içerisinde gerçekleştirilmiştir. Çalışma Kuşadası'nın destinasyon imajı ve destinasyon kişiliği üzerine olması nedeniyle çalışma evreni olarak Aydın Adnan Menderes Üniversitesi Turizm Fakültesi Turizm Rehberliği bölümü öğrencileri alınmıştır. Fakülte öğrenci işlerinden alınan bilgiler doğrultusunda Aydın Adnan Menderes Üniversitesi Turizm Fakültesinde 1,2,3 ve 4. Sınıfında örgün ve ikinci öğretim programları dahil toplam 527 kayıtlı Turizm Rehberliği eğitimi alan öğrenci bulunmaktadır. Çalışma kapsamında öncelikle kayıtlı öğrenci olan 527 katılımcıya ulaşılmak hedeflenmiştir. Bu doğrultuda öğrencilerin dersleri esnasında fakülte yönetiminden ve ilgili dersin öğretim elemanından izin alınarak ders sonlarında anketler katılımcılara dağıtılmıştır. Ancak derslere devam mecburiyeti olmayan öğrencilerin derslere devam etmemeleri dolayısıyla, araştırmanın yapıldığı dönemde ankete katılmak isteyen tüm 
katılımcıların dahil edildiği kolayda örnekleme yöntemi ile toplamda 412 katılımcıya ulaşılarak anket çalışması tamamlanmıştır. Katılımcılara dağıtılan anket 3 bölümden oluşmaktadır. Anketin ilk bölümünde katılımcıların algıladıkları destinasyon imajını belirlemeye yönelik ifadeler, ikinci bölümünde katılımcıların destinasyon kişiliği algılamalarını belirlemeye yönelik ifadeler son bölümünde ise katılımcıların demografik özelliklerini belirlemeye yönelik ifadeler yer almaktadır. Anketin ilk bölümünde yer alan katılımcıların destinasyon imajı algılamalarını ölçmeye yönelik Byon ve Zhang (2010) tarafından geliştirilen 4 boyut (Altyapı, Çekicilikler, Paranın karşıllı̆̆ı, Eğlence) 18 ifadeden oluşan destinasyon imajı ölçeği kullanılmıştır. Anketin ikinci bölümünde yer alan katılımcıların destinasyon kişiliği algılamalarını ölçmeye yönelik Aaker (1997) tarafından geliştirilen 5 boyut (Samimiyet, Heyecan, Yetenek, Seçkinlik ve Sert) ve 42 ifadeden oluşan marka kişiliği ölçeği kullanılmıştır. Anketin üçüncü bölümünde ise katılımcıların okudukları sınıfları ve cinsiyetlerini belirlemeye yönelik ifadeler yer almaktadır. Ölçekler 5'li Likert tipinde hazırlanmıştır. Ölçeklerin normal dağılım varsayımını karşılayıp karşılamadığını test etmek amacı ile Kolmogorov Smirnov Testine başvurulmuş ve $p$ değeri 0,05'in altında olduğu için normal dağılım varsayımını karşılamadıkları tespit edilmiştir. Bu sebeple karşılaştırmalı analizler için non-parametrik testler uygulanmıştır.

Bilimsel araştırmalarda temel olarak tarama ve deneme olmak üzere iki temel yaklaşımdan söz edilmektedir. Tarama modeli araştırmalarında genellikle mevcut veya daha önce var olan bir durumun betimsel olarak ele alınması; deneme modeli araştırmalarında ise neden-sonuç ilişkilerini açıklama yoluyla araştırmacının kontrolünde veri elde etmek amaçlanmaktadır (Karasar, 2009). Buradan hareketle bu araştırmanın modelinin tarama modeli olduğu söylenebilmektedir. Araştırma modeli Şekil 1.'de sunulmaktadır.

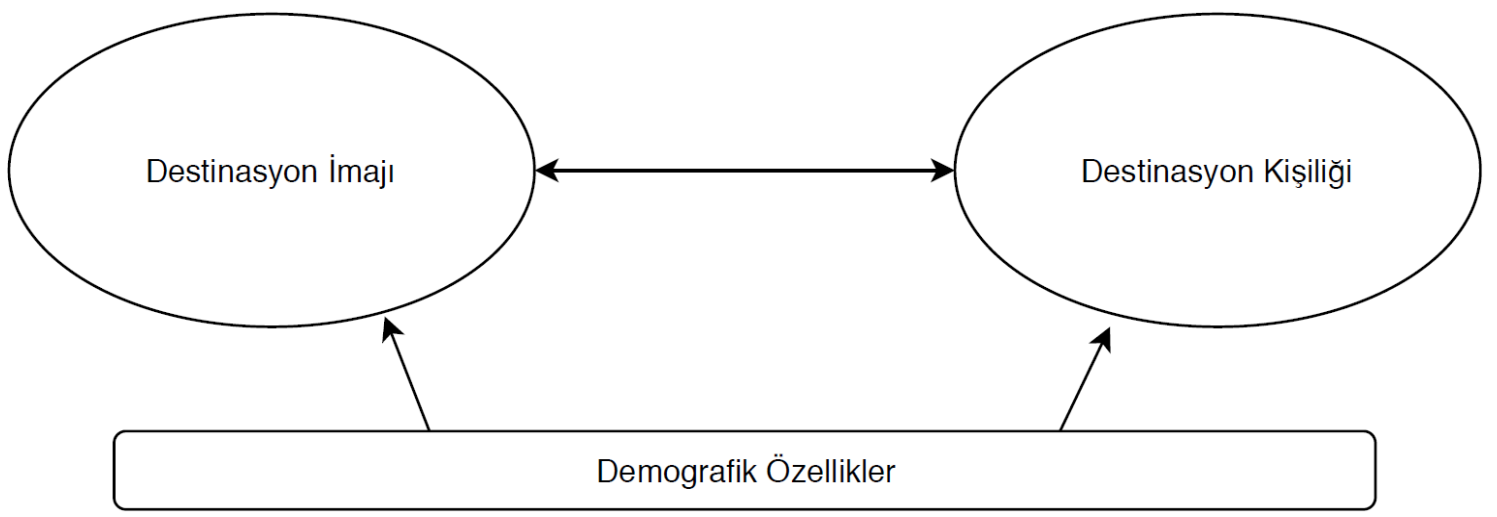

Şekil 1. Araştırma Modeli

\section{BULGULAR}

Bu çalışmada öncelikle destinasyon imajı ve destinasyon kişiliği ölçeklerine yönelik güvenilirlik analizi ve yapı geçerliliği için faktör analizleri gerçekleştirilmiştir. Ardından bu ölçeklere ilişkin ifadelere yönelik ortalamalar ve yüzdelikler verilmiştir. Daha sonra destinasyon imajı ve destinasyon kişiliği ölçeklerindeki boyutlara ilişkin katılımcıların cinsiyet ve sınıflarına göre farklılıklar olup olmadığı tespit edilmiştir. İlgili literatürde geçmiş çalışmalar incelendiğinde cinsiyete ve eğitim durumuna göre farklılık olup olmadığına bakıldığı görülmektedir. Bu sebeple bu çalışmada, öğrenciler üzerinde yapıldığı için eğitim durumu yerine öğrenim gördükleri sınıfa göre farklılık olup olmadığına bakmanın faydalı olacağı düşünülmüştür. Son olarak ise destinasyon imajı ve destinasyon kişiliği boyutları arasındaki ilişkiyi ortaya koymak için korelasyon analizi gerçekleştirilmiştir. 


\section{Destinasyon İmajı Ölçeği Faktör Analizi}

Destinasyon imajı ölçeğine faktör analizi uygulamadan önce değişkenlere güvenilirlik analizi gerçekleştirilmiştir. Yapılan ilk güvenilirlik analizinde ölçeğin Cronbach Alpha güvenilirlik değeri 0,875 olarak belirlenmiş ve bu değer yüksek düzeyde bir güvenilirliği göstermektedir (Özdamar, 1999). Daha sonra ölçeğe bu 18 ifade üzerinden faktör analizi uygulanmıştır. Yapılan faktör analizleri sonucunda 4 ifade 2 boyutta birbirine çok yakın değer aldığından, yüklenme değerleri çok düşük olduğundan ve özdeğerleri düşük olduğundan bu ifade faktör analizinden çıkarılarak faktör analizi tekrarlanmıştır. 14 ifadeye yapılan faktör analizi ile elde edilen Keyser-Meyer-Olkin testi sonucu örneklem yeterlilik değeri 0,848 olduğu için bu değer faktör analizi için uygun bir değer olarak görülmüştür (Büyüköztürk, 2003). Korelasyon matrisinin yeterliliği ve önem düzeyi için Bartlett's Sphericity testi kullanılmıştır. Korelasyon matrisinin yeterliliği ve önem düzeyi 0,000 ve 2282,601 çıkmıştır ve doğrulayıcı faktör analizi yapmak için bu değer kabul edilebilir bir değer olarak alınmıştır. Yapılan faktör analizi sonucu orijinal ölçek ile örtüşen 4 boyut bulunmuş ve bu boyutlar orijinal ölçeğe sadık kalınarak Altyapı, Paranın Karşılı̆̆ı, Eğlence ve Çekicilikler olarak isimlendirilmiştir. Boyutlarının Cronbach Alpha güvenilirlik değerlerinin 0,60'dan büyük olduğu ve oldukça güvenilir olduğu görülmektedir. Yalnızca Çekicilikler boyutu Alpha değerinin 0,589 olduğu ve güvenilirlik düzeyinin görece düşük sayılabileceği görülmektedir (Özdamar, 1999).

Tablo 1. Destinasyon İmajı Ölçeği Faktör Analizi

\begin{tabular}{|c|c|c|c|c|}
\hline & Faktör yükleri & Özdeğer & Açıklanan varyans & Cronbach Alpha \\
\hline ALTYAPI & & 4,957 & 35,410 & 0,645 \\
\hline AY1 & ,763 & & & \\
\hline AY2 & 619 & & & \\
\hline AY3 & 648 & & & \\
\hline ÇEKİCILIIKLER & & 1,622 & 11,589 & 0,589 \\
\hline Ç1 & 635 & & & \\
\hline Ç2 & ,732 & & & \\
\hline Ç3 & 604 & & & \\
\hline Ç4 & ,568 & & & \\
\hline PARANIN KARŞILIĞI & & 1.154 & 8,243 & 0,763 \\
\hline $\mathrm{P} 1$ & ,773 & & & \\
\hline $\mathrm{P} 2$ & 877 & & & \\
\hline P3 & 669 & & & \\
\hline EĞLENCE & & 1.052 & 7,512 & 0,878 \\
\hline E1 & ,780 & & & \\
\hline E2 & 836 & & & \\
\hline E3 & 837 & & & \\
\hline E4 & 695 & & & \\
\hline
\end{tabular}

Faktör yük değerlerinin tamamı 0,568 ve üzerindedir. Verilerin analizinde varimax rotasyonu kullanılmıştır. Faktör analizinde, öz değerleri 1'in üzerinde olan veriler değerlendirmeye alınmıştır. Faktör matrisine bakıldığında değişkenlerin 4 faktör altında toplandığı ve bu 4 faktörün toplam varyansın \%62,754'ünü açıklamakta olduğu görülmektedir. Bu değerler 4 faktörün 14 değişken tarafından açıklanan varyansı açıklayabilme kabiliyetinde olduğunu göstermektedir. Bundan sonraki destinasyon imajı ölçeği ile ilgili analizlerde 4 boyut (Altyapı, Paranın Karşılı̆̆ı, Eğlence ve 
Çekicilikler) kullanılmıştır. Byon ve Zhang (2010)'un geliştirmiş olduğu ölçeğin kullanıldığı diğer araştırmalar incelendiğinde; ulaşılan boyutlar, Sağlık ve Türkeri (2015), Öztürk ve Şahbaz (2017)'nin sonuçları ile örtüşmektedir.

\section{Destinasyon Kişiliği Ölçeği Faktör Analizi}

Aaker (1997) tarafından geliştirilen ölçeğin orijinali 5 boyut ve 42 ifadeden oluşmaktadır. Destinasyon kişiliği ölçeğine faktör analizi uygulamadan önce değişkenlere güvenilirlik analizi gerçekleştirilmiştir. Yapılan ilk güvenilirlik analizinde ölçeğin genel güvenilirliği 0,959 Cronbach Alpha değeri olarak belirlenmiş ve bu değer yüksek düzeyde bir güvenilirliği göstermektedir (Özdamar, 1999). Daha sonra ölçeğe bu 42 ifade üzerinden faktör analizleri uygulanmıştır. Yapılan faktör analizleri sonucunda 22 ifade 2 boyutta birbirine çok yakın değer aldığından, yüklenme değerleri çok düşük olduğundan ve özdeğerleri düşük olduğundan bu ifadeler faktör analizinden çıarılarak faktör analizi tekrarlanmıştır. 20 ifadeye yapılan faktör analizi ile elde edilen Keyser-Meyer-Olkin testi sonucu örneklem yeterlilik değeri 0,921 olduğu için bu değer faktör analizi için uygun bir değer olarak görülmüştür (Büyüköztürk, 2003).

Korelasyon matrisinin yeterliliği ve önem düzeyi için Bartlett's Sphericity testi kullanılmıştır. Korelasyon matrisinin yeterliliği ve önem düzeyi ,000 ve 4779,969 çıkmıştır ve faktör analizi yapmak için bu değer kabul edilebilir bir değer olarak alınmıştır. Yapılan faktör analizi sonucu orijinal ölçekte 5 boyut (Samimiyet, Heyecan, Yetenek, Seçkinlik ve Sert) olmasına karşın 4 boyut bulunmuş ve bu boyutlar orijinal ölçeğe sadık kalınarak Yetenek, Samimiyet, Seçkin ve Sert olarak isimlendirilmiştir.

Faktör yük değerlerinin tamamı 0,650 ve üzerindedir. Verilerin analizinde varimax rotasyonu kullanılmıştır. Faktör analizinde, öz değerleri 1'in üzerinde olan veriler değerlendirmeye alınmıştır. Faktör matrisine bakıldığında değişkenlerin 4 faktör altında toplandığı ve bu 4 faktörün toplam varyansın \%66,121'ini açıklamakta olduğu görülmektedir. Bu değerler 4 faktörün 20 değişken tarafından açıklanan varyansı açıklayabilme kabiliyetinde olduğunu göstermektedir. Bundan sonraki destinasyon kişiliği ölçeği ile ilgili analizlerde 4 boyut kullanılmıştır. Aaker, (1997)'nin geliştirmiş olduğu ölçeğin kullanıldığı diğer araştırmalar incelendiğinde ulaşılan boyutlar; Ülkü, Solmaz ve Barakazı (2017)'nin çalışmasında, Heyecan - Entellektüellik, Samimiyet, Sertlik olmak üzere 3 boyut; Türkmen, Atay ve Türkmen (2018)'in çalışmalarında, Yetkinlik - Seçkinlik, Samimiyet, Güven, Heyecan olmak üzere 4 boyut; Dülgaroğlu ve Atay (2019)'un çalışmalarında, Samimiyet - Heyecan, Yetkinlik, Sertlik olmak üzere 3 boyut şeklinde olduğu görülmektedir. Araştırmalarda ulaşılan boyutların farklılık arz etmesinin nedeninin farklı bölgelerde ve farklı örneklemler üzerinde gerçekleştirilmiş oldukları için kültürel farklılıklardan kaynaklandığı düşünülmektedir. 
Tablo 2. Destinasyon Kişiliği Ölçeği Faktör Analizi

\begin{tabular}{|c|c|c|c|c|}
\hline & Faktör yükleri & Özdeğer & Açıklanan varyans & Cronbach Alpha \\
\hline SAMIMIYYET & & 8,567 & 42,833 & 0,852 \\
\hline SAM1 & ,722 & & & \\
\hline SAM2 &, 805 & & & \\
\hline SAM3 & ,753 & & & \\
\hline SAM4 & ,803 & & & \\
\hline SAM5 & ,669 & & & \\
\hline YETENEK & & 2,213 & 11,067 & 0,922 \\
\hline YET1 & 691 & & & \\
\hline YET2 & 679 & & & \\
\hline YET3 & 693 & & & \\
\hline YET4 & ,758 & & & \\
\hline YET5 & 741 & & & \\
\hline YET6 & ,705 & & & \\
\hline YET7 & ,747 & & & \\
\hline YET8 & ,743 & & & \\
\hline YET9 & ,650 & & & \\
\hline SEÇKİN & & 1.409 & 7,044 & 0,843 \\
\hline SEÇ1 & ,787 & & & \\
\hline SEÇ2 & 804 & & & \\
\hline SEÇ3 & 691 & & & \\
\hline SEÇ4 & 679 & & & \\
\hline SERT & & 1.035 & 5,177 & 0,646 \\
\hline SER1 & 790 & & & \\
\hline SER2 & ,785 & & & \\
\hline E3 & 837 & & & \\
\hline E4 & 695 & & & \\
\hline
\end{tabular}

\section{Destinasyon İmajı}

Destinasyon imajı ile ilgili ifadelere katılımcıların vermiş oldukları cevapların dağılımı Tablo 3.'te yer almaktadır.

Tablo 3. incelendiğinde katılımcıların büyük bir çoğunluğunun $(\% 73,5)$ Kuşadası'nın iyi bir alt yapıya sahip olmadığını düşünmektedir. Yine aynı şekilde katılımcıların önemli bir kısmı $(\% 48,5)$ Kuşadası'nın iyi bir hijyen ve temizlik standardına sahip olmadığını düşünmektedir. Çoğunluğunun ise $(\% 38,8)$ ayn konuda kararsız olduğu görülmektedir. Tablo incelendiğinde katılımcıların genellikle \%30 civarında ifadelere kararsızımın yanıtı verdikleri göze çarpmaktadır. Bu durum öğrencilerin Kuşadası'nın destinasyon imajı hakkında olumlu veya olumsuz bir imaja sahip olmadıkları veya bölge hakkında yeterli bilgiye sahip olmadıkları şeklinde yorumlanabilir. 
Tablo 3. Destinasyon İmajı ile İlgili İfadelerin Dağılımı

\begin{tabular}{|c|c|c|c|c|c|c|c|c|c|c|}
\hline & \multicolumn{2}{|c|}{$\begin{array}{c}\text { Kesinlikle } \\
\text { Katılmiyorum }\end{array}$} & \multicolumn{2}{|c|}{ Katılmiyorum } & \multicolumn{2}{|c|}{ Kararsızım } & \multicolumn{2}{|c|}{ Katıliyorum } & \multicolumn{2}{|c|}{$\begin{array}{l}\text { Kesinlikle } \\
\text { Katılıyorum }\end{array}$} \\
\hline & $f$ & $\%$ & f & $\%$ & $\mathbf{f}$ & $\%$ & $f$ & $\%$ & f & $\%$ \\
\hline $\begin{array}{l}\text { Kuşadası iyi bir alt yapıya } \\
\text { sahiptir (Yollar, ulaşım, kamu } \\
\text { hizmetleri vb.) }\end{array}$ & 176 & 42,7 & 127 & 30,8 & 55 & 13,3 & 40 & 9,7 & 14 & 3,4 \\
\hline $\begin{array}{l}\text { Kuşadası iyi bir turistik } \\
\text { bilgilendirme ağına sahiptir } \\
\text { (Turist bilgilendirme } \\
\text { merkezleri). }\end{array}$ & 46 & 11,2 & 91 & 22,1 & 160 & 38,8 & 96 & 23,3 & 19 & 4,6 \\
\hline $\begin{array}{l}\text { Kuşadası iyi bir hijyen ve } \\
\text { temizlik standardına sahiptir. }\end{array}$ & 62 & 15,0 & 138 & 33,5 & 92 & 22,3 & 96 & 23,3 & 24 & 5,8 \\
\hline $\begin{array}{l}\text { Kuşadası doğal çekiciliklere } \\
\text { sahiptir (Parklar, ormanlar } \\
\text { ve/veya yürüyüş yolları) }\end{array}$ & 34 & 8,3 & 67 & 16,3 & 79 & 19,2 & 165 & 40,0 & 67 & 16,3 \\
\hline $\begin{array}{l}\text { Kuşadası'nın güzel bir } \\
\text { manzarası vardır. }\end{array}$ & 22 & 5,3 & 11 & 2,7 & 15 & 3,6 & 151 & 36,7 & 213 & 51,7 \\
\hline Kuşadası iyi bir iklime sahiptir. & 31 & 7,5 & 39 & 9,5 & 71 & 17,2 & 168 & 40,8 & 103 & 25,0 \\
\hline $\begin{array}{l}\text { Kuşadası ilginç kültürel } \\
\text { etkinlikler sunar (Festival } \\
\text { ve/veya konserler). } \\
\end{array}$ & 47 & 11,4 & 90 & 21,8 & 114 & 27,7 & 120 & 29,1 & 41 & 10,0 \\
\hline $\begin{array}{l}\text { Kuşadasi'ndaki konaklama } \\
\text { ücretleri makuldür. }\end{array}$ & 98 & 23,8 & 88 & 21,4 & 127 & 30,8 & 90 & 21,8 & 9 & 2,2 \\
\hline $\begin{array}{l}\text { Kuşadası ziyaret etmek için } \\
\text { ucuz bir yerdir. }\end{array}$ & 97 & 23,5 & 123 & 29,9 & 111 & 26,9 & 63 & 15,3 & 18 & 4,4 \\
\hline $\begin{array}{l}\text { Kuşadası harcanan para için iyi } \\
\text { bir değer sunar. }\end{array}$ & 74 & 18,0 & 91 & 22,1 & 138 & 33,5 & 89 & 21,6 & 20 & 4,9 \\
\hline $\begin{array}{l}\text { Kuşadası mutluluk verici bir } \\
\text { destinasyondur. }\end{array}$ & 41 & 10,0 & 43 & 10,4 & 118 & 28,6 & 162 & 39,3 & 48 & 11,7 \\
\hline $\begin{array}{l}\text { Kuşadası eğlenceli bir } \\
\text { destinasyondur. }\end{array}$ & 31 & 7,5 & 54 & 13,1 & 140 & 34,0 & 142 & 34,5 & 45 & 10,9 \\
\hline $\begin{array}{l}\text { Kuşadası heyecan verici bir } \\
\text { destinasyondur. }\end{array}$ & 39 & 9,5 & 74 & 18,0 & 157 & 38,1 & 105 & 25,5 & 37 & 9,0 \\
\hline $\begin{array}{l}\text { Kuşadası özgün bir } \\
\text { destinasyondur. }\end{array}$ & 32 & 7,8 & 54 & 13,1 & 138 & 33,5 & 148 & 35,9 & 40 & 9,7 \\
\hline
\end{tabular}

\section{Destinasyon Kişiliği}

Destinasyon Kişiliği ile ilgili ifadelere katılımcıların vermiş oldukları cevapların dağılımı Tablo 4'de yer almaktadır. Tablo 4 incelendiğinde katılımcıların çoğunluğu mütevazi (\%45,4), samimi $(45,6)$, gerçek $(\% 54,9)$, cazibeli $(\% 50,5)$, gösterişli $(\% 47,6)$ ve sevimli $(\% 56,8)$ boyutlarında katılıyorum cevabını vermiştir. Buradan hareketle, turizm rehberliği öğrencilerinin Kuşadası'nın destinasyon kişiliğini samimi, mütevazi, gerçek, sevimli, cazibeli ve gösterişli buldukları yorumu yapılabilir. Lider (\%50) ve uzman (\%50) kişilik özelliklerinde katılmıyorum cevabının ağırlık kazandığı görülmektedir. Böylece, turizm rehberliği öğrencilerinin gözünde Kuşadası'nın lider ve uzman bir kişiliğinin olmadığı söylenebilir. Aile yönlü (\%31,1), Dürüst (\%32), Çalışkan $(\% 37,9)$, Emin $(\% 37,4)$, Zeki $(\% 38,1)$, Bilimsel $(\% 33,7)$, Kurumsal $(\% 39,3)$, Başarılı (\%36,2), Üst sınıf (\% 32,3), Kadınsı (\%37,4), Erkeksi (\%40,5), Sert (\%41) boyutlarında ise turizm rehberliği öğrencilerinin yanıtlarının kararsızım seçeneğinde yoğunlaştığı göze çarpmaktadır. Genel bir değerlendirme yapıldığında, turizm rehberliği öğrencilerinin gözünde, Kuşadası'nın destinasyon kişiliğinin; samimi, mütevazi, sevimli, gerçek, cazibeli kişilik özelliklerine daha eğilimli olduğu, zeki, bilimsel, kurumsal, üst sınıf, sert gibi kişilik özelliklerinin ise Kuşadası ile çok fazla bağdaştırılmadığı söylenebilmektedir. 
Tablo 4. Destinasyon Kişiliği ile İlgili İfadelerin Dağılımı

\begin{tabular}{|c|c|c|c|c|c|c|c|c|c|c|}
\hline & \multicolumn{2}{|c|}{$\begin{array}{c}\text { Kesinlikle } \\
\text { Katılmıyorum }\end{array}$} & \multicolumn{2}{|c|}{ Katılmiyorum } & \multicolumn{2}{|c|}{ Kararsızım } & \multicolumn{2}{|c|}{ Katılıyorum } & \multicolumn{2}{|c|}{$\begin{array}{l}\text { Kesinlikle } \\
\text { Katılıyorum }\end{array}$} \\
\hline Aile yönlü & 48 & 11,7 & 86 & 20,9 & 128 & 31,1 & 120 & 29,1 & 30 & 7,3 \\
\hline Mütevazı & 45 & 10,9 & 89 & 21,6 & 91 & 22,1 & 151 & 36,7 & 36 & 8,7 \\
\hline Dürüst & 57 & 13,8 & 106 & 25,7 & 132 & 32,0 & 89 & 21,6 & 28 & 6,8 \\
\hline Samimi & 51 & 12,4 & 76 & 18,4 & 97 & 23,5 & 152 & 36,9 & 36 & 8,7 \\
\hline Çalışkan & 52 & 12,6 & 100 & 24,3 & 156 & 37,9 & 75 & 18,2 & 29 & 7,0 \\
\hline Emin & 38 & 9,2 & 93 & 22,6 & 154 & 37,4 & 99 & 24,0 & 28 & 6,8 \\
\hline Zeki & 47 & 11,4 & 92 & 22,3 & 157 & 38,1 & 91 & 22,1 & 25 & 6,1 \\
\hline Bilimsel & 78 & 18,9 & 129 & 31,3 & 139 & 33,7 & 50 & 12,1 & 16 & 3,9 \\
\hline Kurumsal & 57 & 13,8 & 103 & 25,0 & 162 & 39,3 & 68 & 16,5 & 22 & 5,3 \\
\hline Üst sinıf & 73 & 17,7 & 124 & 30,1 & 133 & 32,3 & 52 & 12,6 & 30 & 7,3 \\
\hline Cazibeli & 45 & 10,9 & 74 & 18,0 & 85 & 20,6 & 159 & 38,6 & 49 & 11,9 \\
\hline Gösterişli & 46 & 11,2 & 72 & 17,5 & 98 & 23,8 & 149 & 36,2 & 47 & 11,4 \\
\hline Sevimli & 41 & 10,0 & 45 & 10,9 & 92 & 22,3 & 183 & 44,4 & 51 & 12,4 \\
\hline Kadınsı & 57 & 13,8 & 79 & 19,2 & 154 & 37,4 & 87 & 21,1 & 35 & 8,5 \\
\hline Erkeksi & 66 & 16,0 & 86 & 20,9 & 167 & 40,5 & 68 & 16,5 & 25 & 6,1 \\
\hline Sert & 55 & 13,3 & 95 & 23,1 & 169 & 41,0 & 57 & 13,8 & 36 & 8,7 \\
\hline
\end{tabular}

\section{Cinsiyete Göre Destinasyon İmajı ve Destinasyon Kişiliği}

Katılımcıların cinsiyetlerinin katılımcıların algıladıkları destinasyon imajı ve destinasyon kişiliği algılamalarında fark yaratıp yaratmadığını belirlemek üzere kurulan hipotez aşağıdaki gibidir. 
Ho: Katılımcıların cinsiyetlerine göre algıladıkları destinasyon imajı ve destinasyon kişiliği arasında bir fark yoktur.

$H_{1}$ : Katılımcıların cinsiyetlerine göre algıladıkları destinasyon imajı ve destinasyon kişiliği arasında bir fark vardır.

Katılımcıların cinsiyetlerine göre algıladıkları destinasyon imajı ve destinasyon kişiliği boyutlarında farklılık olup olmadığını belirlemek üzere yapılan Mann-Whitney U testi sonuçları tablo 5 'te verilmiştir.

Tablo 5. Cinsiyete Göre Destinasyon İmajı ve Kişiliği

\begin{tabular}{|c|c|c|c|c|c|c|}
\hline & Cinsiyet & $\mathbf{N}$ & Sira Ortalamas1 & Sira Toplamı & $\mathrm{Z}$ & p \\
\hline \multirow[t]{3}{*}{ Altyapı } & Kadın & 196 & 217,49 & 42628,00 & \multirow[t]{3}{*}{$-1,799$} & \multirow[t]{3}{*}{072} \\
\hline & Erkek & 216 & 196,53 & 42450,00 & & \\
\hline & Toplam & 412 & & & & \\
\hline \multirow[t]{3}{*}{ Çekicilikler } & Kadın & 196 & 206,90 & 40552,50 & \multirow[t]{3}{*}{,- 065} & \multirow[t]{3}{*}{ 948 } \\
\hline & Erkek & 216 & 206,14 & 44525,50 & & \\
\hline & Toplam & 412 & & & & \\
\hline \multirow[t]{3}{*}{ Paranın Karşılığı } & Kadın & 196 & 202,04 & 39600,50 & \multirow[t]{3}{*}{,- 728} & \multirow[t]{3}{*}{ 467 } \\
\hline & Erkek & 216 & 210,54 & 45477,50 & & \\
\hline & Toplam & 412 & & & & \\
\hline \multirow[t]{3}{*}{ Eğlence } & Kadın & 196 & 212,63 & 41675,50 & \multirow[t]{3}{*}{$-1,001$} & \multirow[t]{3}{*}{,317 } \\
\hline & Erkek & 216 & 200,94 & 43402,50 & & \\
\hline & Toplam & 412 & & & & \\
\hline \multirow[t]{3}{*}{ Samimiyet } & Kadın & 196 & 218,33 & 42792,00 & \multirow[t]{3}{*}{$-1,926$} & \multirow[t]{3}{*}{054} \\
\hline & Erkek & 216 & 195,77 & 42286,00 & & \\
\hline & Toplam & 412 & & & & \\
\hline \multirow[t]{3}{*}{ Yetenek } & Kadın & 196 & 201,85 & 39562,50 & \multirow[t]{3}{*}{,- 756} & \multirow[t]{3}{*}{ 449 } \\
\hline & Erkek & 216 & 210,72 & 45515,50 & & \\
\hline & Toplam & 412 & & & & \\
\hline \multirow[t]{3}{*}{ Seçkin } & Kadın & 196 & 210,37 & 41233,00 & \multirow[t]{3}{*}{,- 632} & \multirow[t]{3}{*}{,528 } \\
\hline & Erkek & 216 & 202,99 & 43845,00 & & \\
\hline & Toplam & 412 & & & & \\
\hline \multirow[t]{3}{*}{ Sert } & Kadın & 196 & 198,87 & 38979,00 & \multirow[t]{3}{*}{$-1,264$} & \multirow[t]{3}{*}{ 206 } \\
\hline & Erkek & 216 & 213,42 & 46099,00 & & \\
\hline & Toplam & 412 & & & & \\
\hline
\end{tabular}

Farklı cinsiyetteki katılımcıların destinasyon imajı ve destinasyon kişiliği boyutlarındaki algılamaları arasında anlamlı bir farklılık olmadığı görülmüştür. ( $>, 05)$ Buna göre Katılımcların cinsiyetlerine göre algıladıkları destinasyon imajı ve destinasyon kişiliği arasında bir fark yoktur $\left(\mathrm{H}_{0}\right)$ hipotezi desteklenir.

\section{Katılımcıların Öğrenim Gördükleri Sınıfa Göre Destinasyon İmajı ve Destinasyon Kişiliği}

Katılımcıların eğitim gördükleri sınıfa göre algıladıkları destinasyon imajı ve destinasyon kişiliği boyutlarında fark olup olmadığını analiz etmek için kurulan hipotezler şöyledir;

$\mathrm{H}_{0}$ : Katılımcların sınıflarına göre algıladıkları destinasyon imajı ve destinasyon kişiliği arasında bir fark yoktur.

Hı: Katılımcıların sınıflarına göre algıladıkları destinasyon imajı ve destinasyon kişiliği arasında bir fark vardır. 
Tablo 6. Sınıfa Göre Destinasyon İmajı ve Destinasyon Kişiliği

\begin{tabular}{|c|c|c|c|c|c|c|c|}
\hline & Sinif & $\mathbf{N}$ & $\begin{array}{c}\text { Sira } \\
\text { Ortalamasi }\end{array}$ & $\mathrm{X}^{2}$ & sd & $\mathrm{p}$ & Fark Durumu \\
\hline \multirow[t]{5}{*}{ Altyapi } & 1 & 102 & 253,41 & \multirow[t]{5}{*}{30,259} & \multirow[t]{5}{*}{3} & \multirow[t]{5}{*}{,000 } & \multirow{5}{*}{$\begin{array}{l}1-4 \\
3-4\end{array}$} \\
\hline & 2 & 85 & 199,64 & & & & \\
\hline & 3 & 88 & 216,03 & & & & \\
\hline & 4 & 137 & 169,70 & & & & \\
\hline & Toplam & 412 & & & & & \\
\hline \multirow[t]{5}{*}{ Çekicilikler } & 1 & 102 & 213,84 & \multirow[t]{5}{*}{4,179} & \multirow[t]{5}{*}{3} & \multirow[t]{5}{*}{,243 } & \multirow[t]{5}{*}{ Fark Yok } \\
\hline & 2 & 85 & 188,75 & & & & \\
\hline & 3 & 88 & 222,69 & & & & \\
\hline & 4 & 137 & 201,65 & & & & \\
\hline & Toplam & 412 & & & & & \\
\hline \multirow[t]{5}{*}{ Paranın Karşılığı } & 1 & 102 & 210,27 & \multirow[t]{5}{*}{1,897} & \multirow[t]{5}{*}{3} & \multirow[t]{5}{*}{, 594} & \multirow[t]{5}{*}{ Fark Yok } \\
\hline & 2 & 85 & 217,20 & & & & \\
\hline & 3 & 88 & 193,34 & & & & \\
\hline & 4 & 137 & 205,51 & & & & \\
\hline & Toplam & 412 & & & & & \\
\hline \multirow[t]{5}{*}{ Eğlence } & 1 & 102 & 218,21 & \multirow[t]{5}{*}{7,152} & \multirow[t]{5}{*}{3} & \multirow[t]{5}{*}{,067 } & \multirow[t]{5}{*}{ Fark Yok } \\
\hline & 2 & 85 & 204,65 & & & & \\
\hline & 3 & 88 & 225,60 & & & & \\
\hline & 4 & 137 & 186,66 & & & & \\
\hline & Toplam & 412 & & & & & \\
\hline \multirow[t]{5}{*}{ Samimiyet } & 1 & 102 & 232,56 & \multirow[t]{5}{*}{21,787} & \multirow[t]{5}{*}{3} & \multirow[t]{5}{*}{,000 } & \multirow{5}{*}{$\begin{array}{l}1-4 \\
3-4\end{array}$} \\
\hline & 2 & 85 & 202,54 & & & & \\
\hline & 3 & 88 & 234,52 & & & & \\
\hline & 4 & 137 & 171,55 & & & & \\
\hline & Toplam & 412 & & & & & \\
\hline Yetenek & 1 & 102 & 232,34 & 10,107 & 3 & ,018 & $1-4$ \\
\hline & 2 & 85 & 206,21 & & & & \\
\hline & 3 & 88 & 212,43 & & & & \\
\hline & 4 & 137 & 183,64 & & & & \\
\hline & Toplam & 412 & & & & & \\
\hline Seçkin & 1 & 102 & 234,37 & 12,220 & 3 & ,007 & $1-4$ \\
\hline & 2 & 85 & 197,95 & & & & $3-4$ \\
\hline & 3 & 88 & 218,53 & & & & \\
\hline & 4 & 137 & 183,33 & & & & \\
\hline & Toplam & 412 & & & & & \\
\hline Sert & 1 & 102 & 228,67 & 5,586 & 3 & ,134 & Fark Yok \\
\hline & 2 & 85 & 206,65 & & & & \\
\hline & 3 & 88 & 191,94 & & & & \\
\hline & 4 & 137 & 199,25 & & & & \\
\hline & Total & 412 & & & & & \\
\hline
\end{tabular}

Katılımcların okudukları sınıfa göre algıladıkları destinasyon imajı ve destinasyon kişiliğinde farklılık olup olmadığını belirlemek üzere yapılan Kruskal Wallis testi sonuçları Tablo 6'da verilmiştir. Farklı sınıflarda öğrenim gören katılımcların destinasyon imajı boyutlarından altyapı boyutunda, destinasyon kişiliği boyutlarından ise samimiyet, yetenek ve seçkin boyutlarında anlamlı farklılıklar yaşadıkları görülmektedir. Bu farklılıkların hangi gruplar arasında olduğunu tespit etmek için Post Hoc testlerinden yararlanılmıştır. Yapılan bu analiz sonucunda tüm boyutlarda 1. ve 4. Sinıflar arasında farklılıklar olduğu tespit edilmiştir. Bunun dışında yetenek boyutu dışındaki diğer boyutlarda 3. ve 4. sınıfta öğrenim gören öğrencilerin yanıtları arasında anlamlı bir farklılık bulunduğu göze çarpmaktadır. 1. ve 4. Sınıflar arasında öğrencilerin hem yaşları arasında farklılıklar olması hem de alınan dersler arasında ciddi farklar olması nedeni ile farklılık olması doğal olarak yorumlanabilir. Ancak 3. ve 4. Sınıfta 
öğrenim gören öğrencilerin arasında bir farklılık olması gerçek manada anlamlı bir farklılığa işaret etmeyebilir veya bu iki grup arasında henüz ortaya koyulmamış ayrıca ele alınması gereken bir durum olduğu düşünülebilir.

\section{Destinasyon İmajı ve Destinasyon Kişiliği Arasındaki İlişki}

Katılımcıların algıladıkları destinasyon imajı ve destinasyon kişiliği arasında ilişki olup olmadığını analiz etmek için kurulan hipotezler şöyledir.

Ho: Katılımcıların algıladıkları destinasyon imajı ile destinasyon kişiliği arasında bir ilişki yoktur.

Hı: Katılımcıların algıladıkları destinasyon imajı ile destinasyon kişiliği arasında bir ilişki vardir.

Tablo 7. Destinasyon İmajı ile Destinasyon Kişiliği Arasındaki İlişki

\begin{tabular}{|c|c|c|c|c|c|}
\hline & & Samimiyet & Yetenek & Seçkin & Sert \\
\hline \multirow[t]{2}{*}{ Altyap1 } & rho & $420^{* *+}$ &, $515^{* *}$ & ,392" & ,231" \\
\hline & $p$ & ,000 & ,000 & ,000 & ,000 \\
\hline \multirow[t]{2}{*}{ Çekicilikler } & rho & ,240* & $309^{* *+}$ &, $380^{* *}$ & $191^{* *}$ \\
\hline & $p$ & ,000 & ,000 & ,000 & ,000 \\
\hline \multirow[t]{2}{*}{ Paranın Karşılığ } & rho & $391^{* *}$ & $347^{*+*}$ & $293^{*+}$ &, $148^{* *}$ \\
\hline & $\mathrm{p}$ & ,000 & ,000 & , 000 & ,003 \\
\hline \multirow[t]{2}{*}{ Eğlence } & rho &, $537^{*+}$ &, $582^{* *}$ &, 597 & , 280"* \\
\hline & $\mathrm{p}$ & ,000 & ,000 & 000 & ,000 \\
\hline
\end{tabular}

Korelasyon testinde önem düzeyi değişkenler arasında ilişkinin istatistiksel olarak anlamlı olup olmadığını, korelasyon katsayısı ise ilişkinin gücünü göstermektedir. Sosyal bilimlerde korelasyon katsayısının 0 ile ,30 arasında olması düşük düzeyde bir ilişkiyi, 0,30 ile 0,70 arasında olması orta düzeyde bir ilişkiyi, 0.70 ile 1 arasında olması ise yüksek düzeyde bir ilişkiyi göstermektedir. Korelasyon katsayısının karesi alındığında bir değişkendeki değişimin yüzde kaç diğer değişken tarafından açıklandığı hakkında tahmin yapılabilir (Büyüköztürk, 2003). Katılımcıların algıladıkları destinasyon imajı ile destinasyon kişiliği arasında ilişki olup olmadığını belirlemek üzere yapılan Spearman korelasyon testi sonuçları tablo 7.'de verilmiştir. Tablo 7 incelendiğinde destinasyon imajı ile destinasyon kişiliği alt boyutları arasında istatistiksel olarak anlamlı bir ilişkinin olduğu görülmektedir (tüm p olasılık değerleri 0,01'den küçüktür). Destinasyon kişiliğine ait sert boyutu ile destinasyon imajının tüm boyutları arasında, destinasyon kişiliğinin seçkin boyutu ile destinasyon imajının paranın karşıllı̆ı boyutu arasında ve destinasyon kişiliğinin samimiyet boyutu ile destinasyon imajının çekicilikler boyutu arasında düşük düzeyde $(, 0<$ rho<,30). Bir ilişki görülürken diğer boyutlar arasında orta düzeyde $(, 30<$ rho $<, 70)$ bir ilişki görülmektedir.

\section{TARTIŞMA ve SONUÇ}

Ülkemiz için önemli bir gelir kaynağı olan turizm ile ilgili olarak önemli konulardan bir tanesi destinasyonların etkili bir biçimde pazarlanabilmesidir. Destinasyonların etkili bir biçimde pazarlanabilmesi için de olumlu bir destinasyon imajı ve destinasyon kişiliği özelliklerinin oluşturulması gerekmektedir. Ülkemizdeki turist rehberleri destinasyonların turistlere tanıtılmasında önemli kişilerdir. Turist rehberi bir destinasyon ile ilgili bilgi verirken öncelikle kendisinin o destinasyon ile ilgili olumlu destinasyon imajı ve destinasyon kişiliği algılamasına 
sahip olması gerektiği düşünülmektedir. Her biri turist rehberi adayı olan turizm fakültesi turizm rehberliği öğrencileri için de aynı şekilde olumlu destinasyon imajı ve destinasyon kişiliği algılamasına sahip olmaları, mesleklerini icra ederken inandıkları gibi anlatacakları için bu durum daha iyi ve rahat anlatım yapabilmelerini sağlayacaktır. Bu doğrultuda bu çalışmada Aydın Adnan Menderes Üniversitesi Turizm Fakültesinde öğrenim gören turizm rehberliği bölümü öğrencilerinin Kuşadası ile ilgili algıladıkları destinasyon imajı ve destinasyon kişiliği arasındaki ilişkiyi belirlemek amaçlanmıştır.

Çalışmada öncelikle destinasyon imajı ve destinasyon kişiliği ölçeğine doğrulayıcı faktör analizi uygulanmıştır. Öncelikle destinasyon imajı ölçeğine uygulanan faktör analizi sonucunda Byon ve Zhang (2010) tarafından geliştirilen orijinal ölçeğe paralel olarak 4 boyut elde edilmiştir. Bu sonuçlar, Sağlık ve Türkeri (2015) ve Öztürk ve Şahbaz (2017)'nin sonuçları ile örtüşmektedir. Daha sonra Aaker (1997) tarafından geliştirilen orjinali 5 boyuttan oluşan destinasyon kişiliği ölçeğine faktör analizi uygulanmıştır. Destinasyon kişiliğgi ölçeği faktör analizi sonucu 4 boyut bulunmuştur. Bunun sebebi kültürel farklılıklardan kaynaklanabileceği gibi özgün ölçeğin farklı kişiler üzerinde gerçekleştirilmesinden de kaynaklanabilir. Turizm öğrencilerinin diğer yüksek öğretim bölümlerinde öğrenim gören öğrencilere göre turizm, destinasyon, destinasyon kişiliği gibi hususlarda daha farklı düşünce ve tutumlara sahip olabilecekleri düşünülmektedir. $\mathrm{Bu}$ sebeple ölçeğin boyutlarının farklılık arz etmesi ve ölçeğin daha önceki araştırmacılar tarafından farklı bölgelerde uygulanması da boyutların farklı çıkmasına neden olmuş olabilir. Aynı ölçeğin kullanıldığı diğer araştırmalarda da benzer farklılıkların olması bu durumu destekler niteliktir (Ülkü, Solmaz ve Barakazı, 2017; Türkmen, Atay ve Türkmen, 2018; Dülgaroğlu ve Atay, 2019). Destinasyon imajı boyutları ile destinasyon kişiliği boyutları arasındaki korelasyon analizi sonucunda tüm destinasyon imajı boyutları ile tüm destinasyon kişiliği boyutları arasında istatistiksel olarak anlamlı ilişki olduğu tespit edilmiştir. Bu durum, Zengin, Bahadır ve Toylan (2019)'un Aydın ilinin destinasyon imajı ve destinasyon kişiliği ilişkisini ele aldıkları ve pozitif yönde ilişki tespit ettikleri araştırmanın sonuçları ile paralellik göstermektedir.

Destinasyon imajı ile ilgili katılımcıların büyük bir çoğunluğunun Kuşadası'nın iyi bir alt yapıya sahip olmadığını düşündüğü görülmektedir. Yine aynı şekilde katılımcıların büyük bir çoğunluğu Kuşadası'nın iyi bir hijyen ve temizlik standardına sahip olmadığını düşünmektedir. Destinasyon imajı ile ilgili değişkenlere verilen cevaplar incelendiğinde öğrencilerin birçok değişkende çoğunlukla kararsızım seçeneğini işaretledikleri görülmektedir. Bu durum, öğrencilerin Kuşadası'nın imajı ile ilgili bir belirsizlik yaşadıklarını düşündürmektedir. Destinasyon kişiliği ile ilgili ifadelere verilen cevaplar incelediğinde, destinasyon imajına benzer şekilde katılımcılar birçok özelliğe (Aile yönlü, Dürüst, Çalışkan, Emin, Zeki, Bilimsel, Kurumsal, Başarılı, Üst sınıf, Kadınsı, Erkeksi, Sert) kararsızım cevabını vermişlerdir. Bu durum katılımcıların bir belirsizlik yaşadıkları düşüncesini kuvvetlendirmektedir.

Katılımcıların cinsiyetlerine göre destinasyon imajı ve destinasyon kişiliği algılamalarında herhangi bir farklılık bulunmazken, katılımcıların öğrenim gördükleri sınıflara göre destinasyon imajı ve destinasyon kişiliği algılamalarında farklılıklar bulunmaktadır. Bu farklılıklar 3-4, 1-4 sinıflar arasındaki farklılıklardan kaynaklanmaktadır. Bu durum, son sinıf öğrencilerinin ilk sınıftaki öğrencilere göre hem turizm alanında teorik anlamda hem de o destinasyonda yaşama anlamında daha deneyimli olmalarından kaynaklana farklı düşüncelerinden ileri geliyor olabilir. Öğrenciler son sınıfta özellikle 1. sınıf öğrencilerine göre turizm ile ilgili daha fazla ders almalarından dolayı farklı düşüncelere sahip olmaları olağan bir durum olarak değerlendirilebilir. Bu sonuç, İnanır ve Tetik Dinç (2018)'in rehberlik öğrencilerinin Efes antik kentini ziyaret etme durumlarına bakarak, antik kenti ziyaret edenler 
ve etmeyenler arasında destinasyon kişiliği ile ilgili tüm ifadelerde istatistiksel acıdan anlamlı bir fark tespit ettikleri çalışmanın sonucu ile paralellik göstermektedir.

Bu çalışmada örneklem olarak Aydın Adnan Menderes Üniversitesi Turizm Fakültesi Turizm Rehberliği öğrencileri seçilmiştir. Gelecek araştırmalarda farklı örneklemler üzerinde çalışma gerçekleştirilerek elde edilen sonuçlar karşılaştırılabilir. Bu çalışma öğrencilerin dışında profesyonel turist rehberleri üzerinde de gerçekleştirilebilir. Araştırma sonuçları itibari ile katılımcıların Kuşadası destinasyon imajı ve destinasyon kişiliğine yönelik düşüncelerinde olumsuzluklar bulunmaktadır. Kuşadası'nın destinasyon imajı ve destinasyon kişiliği özelliklerinin olumlu hale getirilmesi için yerel yöneticiler tarafından çalışılması gerekmektedir. Destinasyon imajı ile destinasyon kişiliği arasında ilişkinin çıkması destinasyon pazarlaması alanında çalışan profesyonellere ve yerel yöneticilere bir öneriyi de beraberinde getirmiştir. Destinasyon imajı ve destinasyon kişiliği birlikte düşünülmelidir. Pazarlama açısından bir destinasyon imajı oluşturulurken o destinasyonun kişilik özelliklerinden yararlanılabilir. Destinasyon imajı ve destinasyon kişilik özellikleri destinasyonun tanıtımında da kullanılabilir. $\mathrm{Bu}$ anlamda çalışmada da ele alınan turizm rehberliği öğrencileri ve profesyonel turizm rehberleri ile ortak bir çalışma düzenleyerek geliştirme çalışmaları yapılabilir.

\section{KAYNAKÇA}

Aaker J. L., (1997). Dimensions of Brand Personality, Journal of Marketing Research, 34(3): 347-356.

Ahipaşaoğlu, H. S. (2001). Turizmde Rehberlik, Ankara: Detay Yayıncılık.

Ahmodova E. (2018). The Common/Unique and Cognitive/Conative Model of Destination Image: The Case of Azerbaijan, Suleyman Demirel University, The Journal of Faculty of Economics and Administrative Sciences, 23(19): 333-346.

Allameh S.M., Pool J.K., Jaberi A., Salehzadeh R and Asadi A. (2014). Factors influencing sport tourists' revisit intentions: The role and effect of destination image, perceived quality, perceived value and satisfaction, Asia Pacific Journal of Marketing and Logistics, 27(2): 191-207.

Artuğer S. ve Çetinsöz B. C. (2014). Destinasyon İmajı ile Destinasyon Kişiliği Arasındaki İlişkiyi Belirlemeye Yönelik Bir Araştırma, İşletme Araştırmaları Dergisi, 6(1): 366-384.

Artuğer S. ve Çetinsöz B.C., (2017). The Impact of Destination Image and the Intention to Revisit: A Study Regarding Arab Tourists, European Scientific Journal, 13(5): 82-98.

Artuğer S. ve Ercan F, (2015). Marmaris'in Destinasyon Kişiliğini Belirlemeye Yönelik Bir Araştırma, Uluslararası Sosyal Araştırmalar Dergisi, 8(36): 787-793.

Baloğlu, Ş. and McCleary K. W., (1999). A Model of Destination Image Formation, Annals of Tourism Research, 26(4): 868-897.

Beerli A. and Martin J. D., (2004). Factors Influencing Destination Image, Annals of Tourism Research, 31(3): 657-681.

Bilim Y. ve Bilim, M. B., (2014). Does a Destination have Personality? Personality and Image Issues of a Destination, Athens Journal of Tourism, 1(2): 121-134.

Büyüköztürk Ş. (2003). Sosyal Bilimler için Veri Analizi El Kitabı, Ankara: Pegem Yayıncılık.

Byon K. K. and Zhang J. J., (2010). Development of A Scale Measuring Destination Image, Marketing Intelligence \& Planning, 28(4): 508-532. 
Chen C. and Phou S., (2013). A Closer Look at destination: Image, Personality, Relationship and Loyalty, Tourism Management, 36: 269-278.

Çelik S., Öztürk E. ve Coşkun E. (2019). Turistlerin Destinasyon Kişiliği ve Kalite Algılarının Tekrar Gelme Eğilimleri Üzerindeki Etkileri: İspanya/Endülüs Bölgesi'nde Bir Araştırma, Journal of Tourism and Gastronomy Studies, 7(1): 340-357.

Dülgaroğlu, O. ve Atay, L. (2019). Troya Ören Yeri'nin Destinasyon Kişiliği. Gastroia: Journal of Gastronomy And Travel Research, 3(1): 147-161. DOI: 10.32958/gastoria.509236

Ekinci Y. and Hosany S., (2006). Destination Personality: An Application of Brand Personality to Tourism Destinations, Journal of Travel Research, 45: 127-139.

Guthrie M., Kim H. and Jung J. (2008). The Effects of Facial Image and Cosmetic Usage on Perceptions of Brand Personality, Journal of Fashion Marketing and Management, 12(2): 164-181.

Güzel F. Ö., Şahin İ., Yağmur Y., Erdem Ö., Karasakal S. ve Ünal C., (2018). Antalya'nın Destinasyon Kişiliği ve İmajına İlişkin Keşfedici Bir Araştırma, Journal of Yasar University, 13(50): 125-139.

Hosany S., Ekinci Y. and Uysal M., (2006). Destination Image and Destination Personality: An Application of Branding Theories to Tourism Places, Journal of Business Research 59: 638-642.

İnanır, İ. ve Tetik Dinç, N. (2018). Turizm Rehberliği Öğrencilerinin Efes Antik Kentini Ziyaret Etme Durumlarına Göre Destinasyon Kişiliği Algısı, 1. Ulusal Turizm Rehberliği Kongresi Özet Bildiri Kitabl, $25-27 \quad$ Nisan. https://www.academia.edu/39681006/Turizm_Rehberli\%C4\%9Fi_\%C3\%96\%C4\%9Frencilerinin_ Efes_Antik_Kentini_Ziyaret_Etme_Durumlar\%C4\%B1na_G\%C3\%B6re_Destinasyon_Ki\%C5\%9 Fili\%C4\%9Fi_Alg\%C4\%B1s\%C4\%B1, [Erişim Tarihi: 05.09.2019]

Kim W., Malek K., Kim N. and Kim S., (2017). Destination Personality, Destination Image, and Intent to Recommend: The Role of Gender, Age, Cultural Background, and Prior Experiences, Sustainability, 10(87): 1-18.

Kim H. and Richardson S. L., (2003). Motion Picture Impacts on Destination Images, Annals of Tourism Research, 30(1), 216-237.

Kotler, Philip, and Gertner, David. (2002). Country as Brand, Product, and Beyond: A Place Marketing and Brand Management Perspective. Destination Branding: Creating the Unique Destination Proposition, edited by Nigel Morgan, Annette Pritchard, Roger Pride, 40-56. Oxford: Elsevier.

Morgan, N., Pritchard, A., and Pride, R. (2011). Destination Brands: Managing Place Reputation. Routledge.

Özdamar, K. (1999). Paket Programlar ile İstatistiksel Veri Analizi, Eskişehir: Kaan Yayıncıllk.

Özer S. U., (2015). Şehir Pazarlaması Kapsamında Marka Kişiliği ve Marka Sadakati İlişkisi "Edirne İli Örneği", Beykent Üniversitesi Sosyal Bilimler Dergisi, 8(2): 6-31.

Öztürk, Y., and Şahbaz, R. P. (2017). Algılanan Destinasyon İmajının Tekrar Ziyaret Niyeti ve Tavsiye Davranışı Üzerine Etkisi: Ilgaz Dağı Milli Parkı'nda Bir Araştırma (The Effect of Perceived). Journal of Tourism and Gastronomy Studies, 3-21.

Özüpek, M. N. ve Diker, E. (2013). İletişim Fakültesi Öğrencilerinin Cep Telefonu Markalarına Yönelik İmaj Algısı: Nokia ve Samsung Örneği, E-Journal of New World Sciences Academy NWSAHumanities, 8(1): 100-120. 
Papadimitriou D., Apostolopoulou A. and KAplanidou K., (2015). Destination Personality, Affective Image, and Behavioral Intentions in Domestic Urban Tourism, Journal of Travel Research, 54(3): 302-315.

Sağlık, E., ve Türkeri, İ. (2015). Destinasyon İmajının ve Kişiliğinin Destinasyon Aidiyeti Üzerine Etkisi: Palandöken Kayak Merkezi Örneği. Seyahat ve Otel İşletmeciliği Dergisi, 12(1): 2542.

Tasci, A. D. A., and Gartner, W. C. (2007). Destination Image and Its Functional Relationships. Journal of Travel Research, 45(4): 413-425.

Türkmen S. ve Köroğlu A., (2017). Destinasyon Kişiliği Araştırması: Türkiye-Yunanistan Örneği, Balikesir University the Journal of Social Sciences Institute, 20(37): 397-429.

Türkmen S., Atay L. ve Türkmen E., (2018). Destinasyon Kişiliği, Memnuniyet ve Davranışsal Niyetler Arasındaki İlişkilerin İncelenmesi: Çanakkale Örneği, Journal of Yasar University, 13(49), 22-32.

Umur, M. ve Eren, D. (2015). Destinasyon İmajı ve Destinasyon Kişiliğinin, Ziyaretçi Memnuniyeti ve Geleceğe Yönelik Ziyaretçi Davranışı Üzerine Etkisi: Kapadokya Örneği. Kırıkkale Üniversitesi Sosyal Bilimler Dergisi, 6(1): 271-294.

Ülkü A., Solmaz S. A.ve Barakazı M., (2017). Destinasyon Kişiliğinin Turistlerin Davranışsal Niyetleri Üzerindeki Etkisi: Şanlıurfa Örneği, Uluslararası Sosyal Araştırmalar Dergisi, 10(53): 986994.

What is a Tourist Guide? (2019). http://www.wftga.org/tourist-guiding/what-tourist-guide, [Erişim Tarihi: 18.04.2019]

Zengin, E., Bahadır, N. H. ve Toylan, N. V. (2019). Destinasyon Kişiliği ve Destinasyon İmajı Algısı Arasındaki İlişkilerin Araştııılması: Aydın İli Örneği. Kırklareli Üniversitesi Sosyal Bilimler Dergisi, 3(1): 58-69. 